\title{
Muhasebede İhtiyatlılık Düzeyinin Bankalar Üzerindeki Etkisi
}

\author{
Serpil SENAL a, Burcu ASLANTAŞ ATEŞ ${ }^{\mathrm{b}}$, Ahmet ERKAN ${ }^{\mathrm{c}}$
}

\section{Özet}

Riske karşı temkinli davranılması anlamına gelen ihtiyatlılık kavramı; "koşullu" ve "koşulsuz" şeklinde ikiye ayrılarak incelenmektedir. Bu ayrım; bir koşul ortaya çıtığında riske karşı önlem alma ya da en başından herhangi bir koşul ortada yokken tutucu bir tavır sergileme şeklinde özetlenebilir. Doğaldır ki koşullu ve koşulsuz ihtiyatlılık içeren finansal davranış şekilleri finansal tabloları farklı şekilde etkileyecek; raporların farklılaşmasına yol açacaktır. Yapılan araştırmalarda muhasebe sürecinde ihtiyatlı davranış sergilenmesinin tarafsızlık ve gerçeğe uygun sunum ilkesine aykırı davranılmasına sebep olduğu yönünde eleştiriler bulunmaktadır. Ancak bunun yanında güvenilir bilgi sunmak için söz konusu ilkeye ihtiyaç bulunduğu yönünde de tartışmalar yaşanmaktadır. Bu noktadan hareketle, Borsa İstanbul'da işlem gören bankaların koşulsuz ihtiyatllık düzeyleri ölçülmüş ve bu düzeyin risk alma düzeylerini etkileyip etkilemediği araştırılmıştır. Çalışmanın sonucunda bankaların ihtiyatlılık düzeyleri ile sermaye yeterlilik oranları arasında anlamlı bir ilişki tespit edilmiş ancak aynı ilişkinin bankaların kredi ve mevduat oranı ile koşulsuz ihtiyatlılık düzeyi arasında olmadığı görülmüştür.
Anahtar Kelimeler

İhtiyatlılık

Bankalarda Risk

Sermaye Yeterlilik Oranı

Finansal Raporlamaya İlişkin

Kavramsal Çerçeve

Makale Hakkında

Geliş Tarihi: 28.11.2019

Kabul Tarihi: 12.10 .2020

Doi: $10.18026 /$ cbayarsos.652320

\section{The Effect Of Conservatism Level In Accounting On Banks}

\begin{abstract}
The concept of conservatism which means being cautious towards the risk examined as divided into two that "conditional" and "unconditional". This distinction can be summarized in that taking measure towards the risk when a condition arises or display a conservative attitude without any condition from the beginning. It is natural that forms of financial behavior that include conditional and unconditional prudence will affect financial statements differently; will lead to differentiation of reports. There are criticisms in this direction caused to be treated contrary to impartiality and fair presentation principle of exhibiting conservative behavior in the accounting process in the research done. However, there is also debates that needed to said principle to offer reliable information. Based on this point, the unconditional prudence levels of the banks traded in Borsa Istanbul were measured and it was investigated whether this level affected the risk taking levels. As a result of the study, a significant relationship was determined between the prudence levels of banks and capital adequacy ratios, but it was observed that the same relationship was not between the banks loan and deposit ratio and unconditional prudence level.
\end{abstract}

Keywords

Conservatism

Risk in Banks

Capital Adequacy Ratio

Conceptual Framework for

Financial Reporting

\section{About Article}

Received: 28.11.2019

Accepted: 12.10 .2020

Doi: $10.18026 /$ cbayarsos.652320

\footnotetext{
a Doç. Dr., SDÜ İ̈BF Finans ve Bankacilık Bölümü, Isparta, orcid.org/0000-0002-8681-7526

b Doç. Dr., SDÜ İ̈BF Finans ve Bankacılık Bölümü, orcid.org/0000-0002-8896-5303, (İletişim Yazarı: burcuates@sdu.edu.tr)

c SDÜ Sosyal Bilimler Enstitüsü Doktora Öğrencisi, orcid.org/0000-0002-7440-7933
} 


\section{Giriş}

Bilindiği üzere, Muhasebe ve Finansal Raporlama Standartları kural bazlı değil ilke bazlıdır. Peki ilke ve kural birbirinden ne açıdan farklıdır? İlke; kullanıcının içinde bulunduğu duruma göre yorumunu da ekleyebileceği temel nitelikte daha genel prensiplerdir. Kurallar ise, ilkelere göre daha katı, kesin ve yoruma yer bırakmayan hükümlerdir (Balsarı ve Dalkılıç, 2007). Bir kural genel olarak, bu kuralı koyan kişinin gerçeklere dayanarak belirlediği davranış şeklini zorunlu kılmaktadır. Bir ilke ise, hem gerekli davranış şeklini hem de karar vericilerin ortaya koyduğu genel gerçeklere dayanan kuralları açıklamayı ve yorumlamayı gerektirebilir (Delikanlı, 2011). İlke bazlı yaklaşımla hazırlanan muhasebe standartları daha az kural içermekte ve verdikleri genel ilkeler kullanıcılar tarafından yorumlanmaktadır (Balsarı ve Dalkılıç, 2007).

Muhasebe uygulamaları, standartların oluşumuna kadar gerek muhasebe temel kavramları ve muhasebe ilkeleri gerekse işletmelerin devlet kurumlarına rapor sunma ve vergi verme durumunda olmaları sebepleriyle kural bazlı olmuştur. Muhasebe ve finansal raporlama standartları ise kural bazlılıktan ziyade ilke bazlı olmaya ön ayak olmuştur. Bu sebeple araştırmanın konusunu da oluşturan ihtiyatlılık kavramı gibi yıllardır kullanılagelen muhasebe temel kavramlarının birçoğunu standartlarda görmek mümkün olmamaktadır.

Standartlara ilişkin kavramsal çerçeve "Finansal Raporlamaya İlişkin Kavramsal Çerçeve" adıyla yayımlanmış ve bu çerçevede işletme dışındaki kullanıcılar için hazırlanan ve sunulan finansal tabloların tabi olacakları ilkelere yer verilmiştir. Kavramsal çerçeve 2018 versiyonunda "tarafsız sunum" başlığının altında (madde 2.16) eski versiyonda olmayan "ihtiyatlılık" kavramından bahsedilmiştir. Buna göre; "Tarafsızlık, ihtiyatlı davranışla desteklenir. İhtiyatlılık, belirsizlik koşullarında yargıda bulunurken temkinli davranmaktır. İhtiyatlı davranmak, varlıkların ve gelirin olduğundan yüksek gösterilmemesi ve yükümlülüklerin ve giderlerin olduğundan düşük gösterilmemesi anlamına gelir. Aynı şekilde, ihtiyatlı davranmak varlıkların ve gelirlerin olduğundan düşük, yükümlülüklerin ve giderlerin olduğundan yüksek gösterilmesine izin vermez. Bu tür yanlışlıklar, gelecek dönemlerde gelir veya giderlerin olduğundan yüksek veya düşük gösterilmesine yol açabilir."

TFRS/TMS Tam Set içerisinde kavramsal çerçeveye ek olarak TMS 8 "Muhasebe Politikaları, Muhasebe Tahminlerinde Değişiklikler ve Hatalar Standardı" nda da ihtiyatlılıktan bahsedilmiştir. Bu standartta bilgilerin kullanıcıların ihtiyacına uygun ve güvenilir olması gerektiğini belirtmektedir. Standartta bilginin güvenilir olması için sayılan şartların biri de ihtiyatlı olmasıdır.

Literatürde ihtiyatllık, basiretli olma ve temkinlilik kavramları birbiri yerine kullanılmaktadır. Muhasebenin temel kavramlarından olan ihtiyatlılık aslında tutuculuğun muhasebe uygulamalarına yansımasıdır (Sevilengül, 2016). Yukarıda bahsedilen kavramsal çerçeve ve TMS 8' de kavramın "ihtiyatlılık" şeklinde yer alması da bundan dolayıdır. Bu çalışmada da kavramsal açıdan "ihtiyatlılık" kavramı kullanılmıştır.

Bu kısımda ihtiyatlılığın muhasebe ve finansal raporlama standartlarındaki yeri incelenmiştir. İhtiyatlılık başlı̆̆ 1 altında, bu kavrama ve koşullu, koşulsuz ihtiyatlılık ayrımına değinilmiştir. Çalışmanın daha sonraki bölümde piyasa değeri /defter değeri oranı temel alınarak bankaların 
ihtiyatlılık düzeyleri hesaplanmış ve bankaların ihtiyatlılık düzeylerinin; bankaların sermaye yeterlilik oranı ve kredi/mevduat oranı ile ilişki araştııılmıştır.

\section{İhtiyatlılık}

Muhasebede ihtiyatlılık Sevilengül (2016)'e göre “muhasebe olaylarında temkinli davranılmasını, tarafsız bir muhakeme ile işletmenin karşılaşabileceği risklerin ve belirsizliklerin göz önünde tutulması gerektiğini belirtir. İhtiyatlılığa göre bir gelir ancak gerçekleştikten sonra işletmenin gelirleri arasına katılırken, gider ve zararlar kesinleşmese de ortaya çıktıklarında işletmenin sonuç hesaplarının arasında yerini alır, kârdan düşülür". Karabınar (2005) riskten kaçınma düzeyinin düşük olduğu toplumlarda iyimser bir muhasebe sisteminin söz konusu olduğunu ve ihtiyatlılığın daha az önem taşıdığını belirtmektedir. Tersi şekilde tekdüzelik, statükoculuk ve gizliliğin yüksek olduğu toplumlarda ise tutucu muhasebe sistemi vardır dolayısıyla da riskten korkan ve daha çok önlem almak isteyen bir yapı vardır. İşletme ve ekonomik etkinlikleri çevreleyen belirsizliklerden dolayı finansal raporlama ve muhasebede tedbirli olma davranışı gelenek haline gelmiştir.

Muhasebe düzenleyicileri ve muhasebe raporları hazırlayanlar arasında, ihtiyatlılı̆̆ın önemli bir muhasebe kavramı olduğu konusunda fikir birliği mevcuttur. Çok sayıda ülke tarafından Uluslararası Finansal Raporlama Standardı' nın (UFRS) kabul edilmesiyle birlikte ihtiyatlılık kavramı sorgulanmaya başlamıştır (Zeghal ve Lahmar, 2016). Çünkü ihtiyatlılık, standart belirleyici kuruluşlar tarafından eleştirilmektedir. Bu eleştiri, ihtiyatlılığın finansal tablolar aracılığıyla sunulan bilgilerin tarafsızlığını bozduğu noktasındadır (Erdoğan ve Çubukçu, 2010).

Yöneticiler, işletmenin ilerlemesi ve gelişmesini isterler. Bu amaçla çalışmalarına yön verirler. Ancak bu amacın başarılamadığı zaman da hiç olmazsa işletmenin içinde bulunduğu durumun korunmasını sağlamaya çalışırlar. Bu nedenle muhasebeci daima temkinli olmalıdır. Zarar olasılıklarını kaydetmelidir. Bu durum aslında muhasebecinin sahip olduğu şüpheci bir tutumdur (Cemalcılar ve Önce, 1999). Buradan yola çıkan ihtiyatlılık savunucuları, ihtiyatlılık kavramını temel alarak yapılabilecek herhangi bir yanlışlığın zararının daha az olacağı düşüncesi ile tedbirli davranılması gerektiğini savunmaktadırlar. Bu görüşte, en karamsar tablonun gerçekleşebilme ihtimali düşünüldügünden, olumlu olaylar hemen göz önüne alınmamaktadır. Olası kazançların tanınması ve finansal tablolara alınabilmesi için kanıt gerekliliği bulunduğu savunulur. Risklerin göz önüne alınıp değerlendirilmesine bağlı olarak, tedbirli davranılması, ihtiyatlı anlayışın temelini oluşturmaktadır. Bu görüşe göre, muhasebe işlemleri gerçekleştirilirken, en karamsar olasılığın gerçekleşeceği kabul edilerek, olası kayıplar için de önlemler alınması gerekmektedir. (Erdoğan ve Çubukçu, 2010).

Muhasebede tutuculuğun en yaygın örneği stok değerlemesidir. Eğer değerleme gününde bir stok kaleminin piyasa fiyatı, bu kalemin maliyet fiyatının altındaysa o zaman bu kalemin satışı halinde uğranılacak bir zararı karşılamak üzere, bu stok kalemi satış fiyatı ile değerlenir. Satış fiyatı maliyetinin üzerinde ise değerlemede maliyet fiyatı esas alınır. Genellikle satış fiyatının maliyetin üzerinde olduğu durumlarda muhasebeciler bir satış beklentisiyle aradaki farktan doğan kârı hesaba almazlar (Akdoğan ve Aydın, 1987). 
Basu' ya (1997) göre muhasebeciler, bilançodaki iyi haberleri kötü haberlerden daha yüksek derecede doğrulama gereksinimi içindedirler. Çünkü kötü haberlerin olumsuz etkisi hızlı bir biçimde kazancı olumsuz yönde etkilerken; iyi haberlerin kazanç üzerindeki olumlu etkisi o kadar hızlı gerçekleşmez. Örneğin; gerçekleşmemiş kayıplar gerçekleşmiş gelirden daha çabuk fark edilir. Bu farklılık bir asimetri doğurur.

İhtiyatlılık literatürde koşullu ve koşulsuz olarak iki kısımda incelenmektedir. İki ihtiyatlılık türü arasındaki temel fark; koşullu ihtiyatlılığın ekonomik haberlerin sonuçlarına bağlı olmasıdır. Koşullu ihtiyatlılık, olumsuz ekonomik haberlerin olumlu haberlere göre daha hızlı tanınmasıyla ortaya çıar (Ruch ve Taylor, 2015). Dolayısıyla, koşullu ihtiyatlılıkta olumlu ve olumsuz ekonomik haberler, muhasebe açısından Basu' nun belirttiği şekilde bir asimetrik tanıma ortaya çıkarır. Ekonomik kayıplardan ziyade ekonomik kazançların tanınması için daha güçlü kanıtlara ihtiyaç duyar, daha güçlü kanıtları dayatır. Sonucunda da kayıplar, kazançlardan daha hızlı şekilde yansıtılmış olur. (Guay ve Verrecchia, 2007; alıntılayan, Garcı'a Lara vd., 2011). Bu noktada belirtmek gerekir ki "Kavramsal Çerçeve Versiyon 2018" madde 2.17 de asimetrik bilgiye yer vermiştir. Şöyle ki, "İhtiyatlı davranmak, asimetrik olma ihtiyacını, örneğin yükümlülük ve giderlerden ziyade varlıkların ve gelirin finansal tablolara alınmasını destekleyecek daha ikna edici kanıtlara yönelik sistematik bir ihtiyacın olduğunu ifade etmez. Bu tür bir asimetri, faydalı finansal bilginin niteliksel özelliklerinden biri değildir. Bununla birlikte, bu asimetri, sunulması amaçlanan gerçeğe uygun bilgilerin ihtiyaca en uygun bilgilerin seçilmesini amaçlayan kararların bir sonucuysa, belirli Standartlar asimetrik hükümler içerebilir."

Koşulsuz ihtiyatlılık ise, muhasebe net varlıklarının sürekli olarak değerinin altında raporlanmasıyla meydana gelir. Koşullu ihtiyatlılığın aksine koşulsuz ihtiyatlılık ekonomik haberlere bağlı değildir. Koşulsuz ihtiyatlılık örneğin, araştırma- geliştirme harcamalarını anında gider yazmayı, LIFO stok değerleme yöntemini kullanmayı ve hızlandırılmış amortismanı gerektirir. (Ruch ve Taylor, 2015).

Koşullu ve koşulsuz ihtiyatlılık mali tablolar üzerinde farklı etkilere sahiptir. Koşulsuz ihtiyatlılık ile her dönem aynı muhasebe politikası izleneceği için dönemler itibariyle gelir tablosunda etki doğacaktır. Ancak koşullu ihtiyatlılık uygulamaları ekonomik gelişmelere bağlı olarak gerçekleştiğinden gelir tablosunu sürekli etkilemez. Her ikisinin de bilançoya yansıması varlıkların olduğundan düşük değerde gösterilmesi şeklindedir (Ruch ve Taylor, 2015).

\section{Çalışmanın Amacı, Yöntemi ve Kapsamı}

Bankacılık sektörü piyasalarda aracılık rolünü üstlendiği için ülke ekonomisi içerisinde önemli bir yere sahiptir. Söz konusu sektör ile ilgili olumsuz bir süreç diğer sektörleri de olumsuz etkilemektedir. Bununla birlikte bankacıllk sektöründe rekabet de oldukça yoğundur. Sektördeki bu rekabet yoğunluğu borçlanma maliyetinin azalmasına neden olmaktadır. Çünkü rekabet, bankaların pazarlık gücünü zayıflatmakta, dolayısı ile ihtiyatlı davranmasının önüne geçebilmektedir (Huang, 2018). Ayrıca sektör birçok riskle de karşı karşıyadır. Bu nedenle ihtiyatlılık kavramı bankacılık sektörünün kilit unsurlarındandır. Ulusal ve uluslararası piyasalarda bankaların ihtiyatlı davranmasını sağlayacak düzenlemeler 
mevcuttur. Türkiye'de bankacılık faaliyetlerini düzenleyen Bankacılık Kanunu, Bankacılık Düzenleme ve Denetleme Kurumu'na (BDDK) bankalar ile ilgili koruyucu hükümler koyma yetkisi vermiştir. BDDK, ihtiyatlılık kavramı gereği bankaların kredi ve alacakları için karşılık ayırmasını gerekli kılmaktadır. Karşılık tutarları, BDDK'nın “Bankalarca Kredilerin ve Diğer Alacakların Niteliklerinin Belirlenmesi ve Bunlar için Ayrılacak Karşılıklara İlişkin Usul ve Esaslar Hakkında Yönetmelik" ile düzenlenmektedir. Söz konusu yönetmeliğe göre, bankalar kredi veya alacaklarından dolayı ortaya çıkması muhtemel zararların karşılanabilmesi için genel veya özel karşılık ayırmaktadır. Türkiye Muhasebe Standardı 37 Karşılıklar ve Koşullu Borçlar'da da benzer bir uygulama yer almaktadır.

Mevduat güvence sistemi de ülkemizde bankaların ihtiyatlı davranmasını sağlamaya yönelik düzenlemelerdendir. Buna göre, BDDK tarafından mevduat ile katılım fonu toplamaya yetkili kredi kuruluşlarının faaliyet izinlerinin kaldırılması durumunda hak sahiplerinin karşı karşıya kalacağı kayıpların, devlet tarafından veya bu amaçla kurulan bir yapı tarafından, bir kısmının veya tamamının ödenmesini garanti etmektedir (www.tmsf.gov.tr).

Hem Türkiye'de hem de uluslar arası piyasalarda bankaları ihtiyatlı davranmaya yönelten düzenlemelerden bir diğeri ise Basel uygulamalarıdır. 1970'li yılların başında uluslararası finansal piyasalarda yaşanan finansal çöküşlerle birlikte 1974 yılında G10 olarak isimlendirilen ülkelerin merkez bankaları tarafından Bankacılık Düzenleme ve Denetleme Komitesi (Basel) kurulmuştur. Komitenin temel amacı, dünya piyasasında finansal istikrarı artırmak amacıyla banka gözetimini güçlendirmektir (Zaky ve Soliman, 2017). Söz konusu komite ilk olarak "Sermaye Yeterliliği Uzlaşısı" olarak adlandırılan Basel 1 düzenlemesini uygulamaya koymuştur. Bu düzenleme, bankaların kredi kullandırma sürecinde belli esaslara dikkat etmesini öngörmektedir. Düzenleme bankaların "sermaye yeterlilik oranı" olarak da ifade edilen ,sermaye tutarlarının risk ağırlıklı aktiflere oranının en az \%8 olmasını gerekli kılmıştır. $\mathrm{Bu}$ oran aslında bankaların alabilecekleri risk düzeyine bir sınırlama getirmektedir (Arslan, 2007).

Basel Komitesi, Basel 1 ile ilgili eleştirileri de dikkate alarak 2004 yılında Basel 2'yi yayınlamıştır. Söz konusu düzenleme asgari sermaye yeterliliğinin hesaplanmasında piyasa riski ve kredi riskinin yanına operasyonel riski de dahil etmiştir. Basel 2, bankalarda daha etkin risk yönetim sistemini gerekli kılmış ve piyasa disiplinini geliştirmeyi hedeflemiştir. Böylece bankaların kırılganlığının azaltılması amaçlanmıştır (Yıldırım, 2015). Tüm bunlara rağmen, 2008 yilındaki mortgage krizi ve sonrasında yaşananlar ile, Basel 2 uygulamasının sistematik risklerin tespit edilmesinde ve finansal kırılganlıkların ortadan kaldırılmasında yetersiz kaldığı görülmüş ve 2010 yılında Basel 3 düzenlemesi yayınlanmıştır. BDDK, Basel III ile birlikte yayınladığı "Sermaye Koruma ve Döngüsel Sermaye Tamponlarına İlişkin Yönetmelik'te" bankaların kar paylarını, sermaye yeterliliklerinin sağlanmasına ilişkin olarak, bazı durumlarda bankalarda tutulmasını gerekli kılmaktadır. Böylece, bankaların karşılaşabilecekleri risklere karşı daha ihtiyatlı olması hedeflenmektedir. Buradan hareketle çalışmada öncelikle, Türkiye'deki bankaların koşulsuz ihtiyatlılık düzeyleri incelenmiştir. Koşulsuz ihtiyatlılık düzeyi ile ilgili literatürde; piyasa/defter değeri oranı (Beaver ve Rayn, 2005), gizli rezervler (Zhang,2008), asimetrik zamanlılık (Basu, 1997), negatif tahakkuklar (Givoly ve Hayn,2000), tahakkuk esasına göre asimetrik nakit akışı (Ball's and Shivakumar, 2006) gibi birçok yöntemin kullanıldığı görülmektedir. Çalışma kapsamında koşulsuz 
ihtiyatlılık düzeyinin ölçülmesi için literatürde en sık kullanılan yöntem olan piyasa değeri/defter değeri oranı tercih edilmiştir.

Muhasebede ihtiyatlılık kavramı ile ilgili yapılan çalışmalar aşağıda özetlenmiştir:

Zeytinoğlu ve Polat (2018) çalışmalarında, muhasebede ihtiyatlılı̆̆ı etkileyen faktörleri araştırmıştır. Bu kapsamda panel veri analizinden faydalanarak Borsa İstanbul' da işlem gören işletmelerin 2006-2013 yıllarına ait verilerinden yararlanılmıştır. İhtiyatlılık ile kurumsal yönetim ilişkisinin incelendiği bu çalışmada, kurumsal yönetim uygulamalarının ihtiyatlılığ etkilediği sonucuna ulaşılmıştır.

Erdoğan ve Çubukçu (2010) çalışmalarında, tutuculuğun kurumsal yönetimin amaçlarının gerçekleştirilmesinde etkili olabilecek alanları teorik olarak değerlendirmiştir. Ertuğrul (2014) ise çalışmasında, varlıkların ve borçların gerçek değerleri ile gösterilmesinin ihtiyatlılıktan büyük sapmalara neden olup olmadığını yevmiye kayıtları yardımı ile incelemiştir.

Gör ve Tekin (2018) ise çalışmalarında, Borsa İstanbul'da işlem gören işletmelerin finansal verilerinden faydalanarak muhafazakar muhasebe uygulamaları ile kurumsallaşma arasındaki ilişkiyi incelemiştir. Çalışmanın sonucunda yönetim kurulunun bağımsızlığını arttıran kurumsal yönetim uygulamalarından bazılarının ihtiyatlılık ile ters yönlü ilişkiye sahip olduğu görülmüştür.

Acar ve Aktürk (2009) çalışmalarında, Borsa İstanbul'da işlem gören işletmelerin ihtiyatlılık düzeylerini ölçmek için hisse başına kar ile hisse senedi getirisi arasındaki ilişkiden faydalanmışlardır. Sonuçta çalışma kapsamında yer alan işletmelerde ihtiyatlı uygulamaların olmadığı görülmüştür. Kiseleva (2017) çalışmasında bankaların muhasebe tutuculuğu ve likidite seviyeleri arasındaki ilişkiyi incelemiştir. İhtiyatllık düzeyinin ölçümü için bankaların tahakkuk düzeylerini gösterge olarak kullanmıştır. Çalışma sonucunda bankaların likidite seviyeleri ve muhasebe ihtiyatlılık düzeyleri arasında negatif yönlü bir ilişki tespit edilmiştir.

Yukarıdaki çalışmalardan da hareketle bankaların ihtiyatlılık düzeyleri ölçüldükten sonra bu düzeyin bankaları kredi/mevduat oranı ve sermaye yeterlilik oranı ile ilişkisinin ortaya konulması amaçlanmıştır.

Bankaların varlıkları içerisinde en büyük payın kredilere ait olması ve en önemli temel fon kaynağının da mevduat olması nedeniyle Kredi/Mevduat Oranı (KMO), bankaların uzun dönemli veya yapısal likidite pozisyonları açısından yakından takip edilen göstergelerden biridir. Söz konusu oran bankaların fonlama kaynaklarının istikrarına ilişkin bir gösterge olarak kullanılmaktadır (Alper ve Çapacıŏ̆lu, 2016). Çünkü bankalar mevduat toplar ve bu mevduatları kredi olarak kullandırırlar. Ancak oranın yükselmesi bankanın karlılığını artırabileceği gibi likidite riskini de beraberinde getirmektedir. Dolayısı ile ihtiyatlılık düzeyi yüksek olan bankalarda bu oranın daha düşük olması beklenmektedir. Bu düşünceden hareketle söz konusu oran çalışma kapsamına dahil edilmiş ve ihtiyatlılık düzeyi ile arasındaki ilişkinin ortaya konulması amaçlanmıştır. 
Bankacılık sektörü; temel fonksiyonu gereğince, finansal aracılık işlemlerini gerçekleştirmektedir. Bu çerçevede finansal ürünlerin çeşitlenmesi, teknolojinin hızlı değişimi gibi faktörler bankacılık sektörünün yapısında değişikliklere yol açarken, farklı risk türlerini de ortaya çıkarmaktadır. Bu anlamda; bankaların maruz kaldıkları riskler de çeşitlenerek artış göstermektedir. Bankaların faaliyetlerini sürdürebilmeleri maruz kaldıkları bu riskleri başarıyla yönetmeleri ile ilişkilidir. Geçmişte bankacılık krizlerinin yaşanmasındaki temel sebep olarak, bankaların risklerini yönetememeleri ve sermaye yapılarının riskleri karşılayacak düzeyde olmaması gösterilmektedir (Hazar vd., 2018). Bu kapsamda Basel Uzlaşıları ile birlikte sermeye yeterlilik oranı gündeme gelmiştir. (Ak Bingül, 2018). Sermaye yeterliliği, bankaların maruz kaldıkları risklere karşılık, mali yükümlülüklerini karşılayacak düzeyde likit varlığa sahip olup olmadıklarını ifade etmektedir. Basel kapsamında oranın en az \%8 olması talep edilmektedir. Ancak bankalarda bu oran daha da çıabilmektedir. Bu durumdan hareketle bankaların ihtiyatlılık düzeyleri arttıkça riske karşı korunma seviyelerinin de artacağı düşünülerek sermeye yeterlilik oranın (SYO) da buna paralel artması beklenmektedir. Bu doğrultuda bankaların ihtiyatlılık düzeyi ile SYO arasındaki ilişkiyi ortaya koymak amacıyla söz konusu oran da çalışma kapsamına dahil edilmiştir.

Çalışmada test edilmek üzere aşağıdaki hipotezler oluşturulmuştur:

$\mathrm{H}_{1}$ : Bankaların ihtiyatlılık düzeyi ile sermaye yeterlilik oranı arasında anlamlı bir ilişki vardır.

$\mathrm{H}_{2}$ : Bankaların ihtiyatlılık düzeyi ile kredi/mevduat oranı arasında anlamlı bir ilişki vardır.

Araştırmada oluşturulan hipotezler, basit doğrusal regresyon analiz ile test edilmiştir. Basit doğrusal regresyon analizi, bir bağımlı değişken ile bir bağımsız değişken arasındaki ilişkinin bir matematiksel eşitlik ile açıklanması sürecidir. Basit doğrusal regresyon analizinin uygulanması için verilerin normal dağılım göstermesi gerekmektedir (Kalaycı vd., 2005). Basit doğrusal regresyon modeli aşağıdaki gibidir:

$$
Y=a+\beta_{1} X_{1}+\varepsilon
$$

\section{Y: Bağımlı değişken}

$\beta$ : Açılayıcı değişken

$\varepsilon$ : Hata terimi

$\alpha=$ Sabit katsay 1

Araştırmada Borsa İstanbul'da yer alan 13 banka çalışma kapsamına dahil edilmiştir. Ancak bu bankalardan iki tanesi mevduat kabul etmemesi nedeniyle elenmiştir. Banka verilerinin toplanmasında Kamuyu Aydınlatma Platformundan yararlanılmıştır. Söz konusu bankaların 2013-2017 yılları arası verileri çalışma kapsamına dahil edilmiştir.

\section{Çalışmanın Bulguları}

Çalışmada parametrik bir test olan doğrusal regresyon analizinin kullanılması nedeniyle öncelikle değişkenlerin normal dağılım gösterip göstermedikleri incelenmiştir. 
Tablo 1. Normallik Dağılımı

\begin{tabular}{lcccccccccc}
\hline Değişk. & Std. Hata & Std. Sap. & Vary. & Min & Max & Ort. & Ortan. & Çarp. & Bas. & $\begin{array}{c}\text { Kol.- } \\
\text { Sim. }\end{array}$ \\
\cline { 3 - 4 } & 0,00593 & 0,04398 & 0,002 & 1,08 & 1,29 & 1,1710 & 1,161 &, 673 &, 184 & 0,160 \\
& & & & & & & & & & \\
İhtiyatll1ık & 0,00514 & 0,03815 & 0,001 & 0,07 & $-0,15$ & 0,0738 & 0,0714 &, 712 &, 124 & 0,108 \\
KMO & 0,004898 & 0,36328 & 0,132 & 0,53 & 2,13 & 1,1380 & 1,0306 &, 465 &, 974 & 0,67 \\
\hline
\end{tabular}

Normallik testi için veriler öncelikler şekilsel olarak incelenmiştir. Daha sonraki süreçte verilerin çarpıklık ve basıklık değerlerine bakılmış ve son olarak da verilere KolmogorovSmirnov testi uygulanmıştır. Verilerin şekilsel olarak incelenebilmesini sağlamak amacıyla Tablo 1'de verilerin minimum, maksimum, ortalama ve standart sapma değerleri verilmiştir. Bununla birlikte Tablo 1'de normallik varsayımı analizinin ikinci aşaması için gerekli olan basıklık ve çarpıklık değerleri verilmiştir. Çarpıklık ve basıklık değerlerinin \%5 güven aralığı için $-2,58$ ile $+2,58$ arasında olması gerekmektedir. Tablo 1'de görüldüğü üzere çalışmada kullanılan değişkenlerin çarpıklık ve basıklık değerleri söz konusu aralıktadır. Normallik testinin son aşaması olan Kolmogorov-Smirnov testinin sonuçları da Tablo 1'de gösterilmektedir. Buna göre Kolmogorov-Smirnov testinin sonuç değerinin anlamlılık düzeyinin 0,05'in üzerinde olması verilerin normal dağılım gösterdiğini ifade etmektedir (Liu vd.,2005).

Çalışmanın bundan sonraki aşamasında öncelikle bankaların sermaye yeterlilik oranı ile ihtiyatlılık düzeyi arasındaki ilişki incelenmiştir.

Tablo 2. SYO'na İlişkin Varyans Analizi Tablosu

\begin{tabular}{llllllll}
\hline Model & $\begin{array}{l}\text { Düzeltilmiş } \\
\text { R Kare }\end{array}$ & $\begin{array}{l}\text { Kareler } \\
\text { Toplamı }\end{array}$ & $\mathrm{df}$ & $\begin{array}{l}\text { Kareler } \\
\text { Ortalaması }\end{array}$ & $\mathrm{F}$ & $\begin{array}{l}\text { Anlamllık } \\
\text { Düzeyi (p) }\end{array}$ & $\begin{array}{c}\text { Durbin } \\
\text { Watson }\end{array}$ \\
\hline $\begin{array}{l}\text { Regresyon } \\
\text { Artık }\end{array}$ &, $272^{\mathrm{a}}$ &, 008 & 1 &, 008 & 4,231 &, $035^{\mathrm{b}}$ & \\
$\begin{array}{l}\text { Değer } \\
\text { Toplam }\end{array}$ & & & 53 &, 002 & & & 1,741 \\
\hline
\end{tabular}

Tablo 2' de yer alan regresyon sonucunda, modelin anlamlılığını ifade eden F değerinin 4,231 olması ve bu değerin anlamlılığını gösteren p değerinin $(, 035)$ anlamlılık düzeyi olan $0,05^{\prime}$ ten küçük olması bankaların ihtiyatlılık düzeylerinin, sermaye yeterlilik oranlarındaki farklılığ önemli ölçüde açıkladığını ve modelin istatistiki olarak anlamlı olduğunu göstermektedir. Buna göre $\mathrm{H}_{1}$ hipotezi kabul edilmiştir. Tablo 2 'de yer alan düzeltilmiş $\mathrm{R}$ Kare sonucunun $\% 27$ olması, bankaların sermaye yeterlilik oranındaki değişimin \%27'sinin, bankaların ihtiyatlılık düzeyi ile açıklandığını göstermektedir. Parametrik bir test olan regresyon analizinin uygulanabilmesi için gerekli olan varsayımlardan biri de değişkenler arasında otokorelasyonun olmamasıdır. Buna göre Durbin Watson katsayısı otokorelasyonu test etmek 
için kullanılır. Söz konusu değerin 1.5 ile 2.5 arasında olması arzulanır (Kalaycı, 2005). Tablo 2'de görüldügü üzere Durbin Watson katsayısı 1,741 olarak hesaplanmıştır. Buna göre değişkenler arasında bir otokorelasyon mevcut değildir.

Tablo 3. SYO' na İlişkin Regresyon Analizi Katsayısı ve Test Sonuçları

\begin{tabular}{|c|c|c|c|c|c|}
\hline \multirow[t]{3}{*}{ Model } & \multicolumn{2}{|c|}{ Standartlaştırılmamış } & \multirow{2}{*}{$\begin{array}{l}\text { Standartlaştırılmı̧ } \\
\text { Katsayı }\end{array}$} & \multirow[t]{3}{*}{$t$} & \multirow{3}{*}{$\begin{array}{l}\text { Anlamlılık } \\
\text { Düzeyi }\end{array}$} \\
\hline & Katsay & & & & \\
\hline & B & Standart Hata & Beta & & \\
\hline (Sabit) & 1,208 & ,019 & & 63,250 & ,000 \\
\hline İhtiyatlılık &,- 033 & ,016 &,- 272 & $-2,057$ & ,045 \\
\hline
\end{tabular}

Tablo 3'de görüldüğü üzere, modelde sabit katsayı 1,208 bulunmuştur. İhtiyatlılık düzeyini temsil eden değişkenin katsayısı ise $(-0,033)$ olarak hesaplanmıştır.

$p$ değerlerinin 0,05 anlamlılık değerinden büyük olması katsayıların istatiksel olarak anlamlı olduğunu göstermektedir. Bu durumda katsayllar tablosuna göre regresyon formülü aşağıdaki gibi formüle edilebilmektedir:

$$
Y=a+\beta_{1} X_{1}+\varepsilon
$$

$\mathrm{SYO}=1,208-0,033$ ihtiyatlilık $+\varepsilon$

Çalışmanın bundan sonraki aşamasında ise, bankaların ihtiyatlılık düzeyleri ile Kredi /Mevduat oranları arasındaki ilişki incelenmiştir.

Tablo 4. K/M Oranına İlişkin Varyans Analizi Tablosu

\begin{tabular}{llllllll}
\hline Model & $\begin{array}{l}\text { Düzeltilmiş } \\
\text { R Kare }\end{array}$ & $\begin{array}{l}\text { Kareler } \\
\text { Toplamı }\end{array}$ & df & $\begin{array}{l}\text { Kareler } \\
\text { Ortalaması }\end{array}$ & F & $\begin{array}{l}\text { Anlamlılık } \\
\text { Düzeyi (p) }\end{array}$ & $\begin{array}{l}\text { Durbin } \\
\text { Watson }\end{array}$ \\
\hline $\begin{array}{l}\text { Regresyon } \\
\text { Artık }\end{array}$ &, 017 & 2,687 & 1 &, 047 &, 935 &, $338^{\mathrm{b}}$ & \\
$\begin{array}{l}\text { değer } \\
\text { Toplam }\end{array}$ & & 53 &, 051 & & & 1,269 \\
\hline
\end{tabular}

Tablo 4'de görüldüğü üzere modelin anlamlılığını ifade eden F istatistiğinin 0,935 ve bu değerin anlamlılı̆̆ını gösteren $\mathrm{p}$ değerinin $(0,333)$ olması modelin istatistiksel olarak anlamlı olmadığını göstermektedir. 
Tablo 5. K/M Oranına İlişkin Regresyon Analizi Katsayısı ve Test Sonuçları

\begin{tabular}{|c|c|c|c|c|c|c|}
\hline \multirow{4}{*}{\multicolumn{2}{|c|}{ Model }} & \multirow{2}{*}{\multicolumn{2}{|c|}{$\begin{array}{l}\text { Standartlaştırılmamış } \\
\text { Katsayı }\end{array}$}} & \multirow{4}{*}{$\begin{array}{l}\text { Standartlaştırılmış } \\
\text { Katsayı } \\
\text { Beta }\end{array}$} & \multirow[t]{4}{*}{$\mathrm{t}$} & \multirow{4}{*}{$\begin{array}{l}\text { Anlamlılık } \\
\text { Düzeyi (p) }\end{array}$} \\
\hline & & & & & & \\
\hline & & B & Standart & & & \\
\hline & & & Hata & & & \\
\hline & (Sabit) & 1,232 & 101 & & 12,230 & ,000 \\
\hline & İhtiyatlılık & -,082 & ,084 &,- 132 &,- 967 & ,338 \\
\hline
\end{tabular}

Tablo 5 modeldeki katsayıların tahmini değerlerini göstermektedir. Ayrıca bu tabloda söz konusu katsayıların istatistiksel olarak anlamlılığını gösteren $t$ değerleri yer almaktadır. Buna göre p >0.05 olduğu için ihtiyatlılık değişkeninin katsayısı istatiksel olarak anlamlı bulunmamıştır. $\mathrm{Bu}$ sonuçlara göre $\mathrm{H}_{2}$ "hipotezi bankaların ihtiyatlılık düzeyi ile kredi/mevduat oranı arasında anlamlı bir ilişki vardır" hipotezi reddedilmiştir.

\section{Sonuç}

Çalışma kapsamında öncelikle olabileceğin en kötüsüne karşı bir davranış şekli belirleme olarak ifade edilen ihtiyatlılık kavramı, koşullu ve koşulsuz ihtiyatlılık ayrımı da dikkate alınarak incelenmiştir. Kavramın tanımından da anlaşılacağı üzere işletmelerin ihtiyatlılık düzeylerinin risk alma düzeylerini de etkilemesi muhtemeldir. Bu düşünceden hareketle bankaların risk alma düzeylerinin bir göstergesi olan koşulsuz ihtiyatlılık düzeyleri hesaplanmıştır. Sonrasında ise sermaye yeterlilik oranı ve kredi/mevduat oranları ile bankaların koşulsuz ihtiyatlılık düzeyleri arasındaki ilişki incelenmiştir. Bu ilişkinin değerlendirilmesi için basit doğrusal regresyon analizi kullanılmıştır. Yapılan analiz sonucunda bankaların koşulsuz ihtiyatlılık düzeyleri ile sermaye yeterlilik oranları arasında anlamlı bir ilişki tespit edilmiştir. Buna göre bankaların sermaye yeterlilik oranlarındaki değişimin \%27'si koşulsuz ihtiyatlılık düzeylerindeki değişimle ile açıklanmaktadır. Ancak aynı ilişki kredi/mevduat oranı ve koşulsuz ihtiyatlılık düzeyi arasında tespit edilememiştir. Kredi/mevduat oranının yükselmesi bankaların karlılığını artırırken bunun yanında riskini de artırmaktadır. Bu nedenle ihtiyatlılık düzeyi yüksek olan bankaların risk alma düzeylerinin de düşük olması beklendiği için, bu dönemlerde kredi/mevduat oranlarının da düşük olması beklenmektedir. Ancak çalışmada böyle bir ilişki bulunamamıştır. Çünkü son yıllarda Türkiye'deki bankaların kredi/mevduat oranları incelendiğinde genellikle bankaların oranlarında ciddi bir yükseliş görülmektedir. Bunun sebebinin de bankaların ihtiyatlılık düzeyinden ziyade genişleyici maliye politikası ve kredi garanti fonu destekli kredilerin etkisinin olabileceği düşünülmektedir. 


\section{Kaynakça}

Acar, D.\& Aktürk, A. (2009). Muhasebede İhtiyatlılık Kavramı ve İMKB Sınai Endeksinde İşlem Gören İşletmelerde İhtiyatlılık Üzerine Bir Araştırma. Afyon Kocatepe Üniversitesi I.I. B.F Dergisi, XI (1).

Ak Bingül, B. (2018). Bankacılık Sisteminde Risk ve Sermaye Yeterliliği. Ĭğdır Üniversitesi Sosyal Bilimler Dergisi, Sayı:14 (Nisan).

Akdoğan, N \& Aydın, H. (1987). Muhasebe Teorileri. Gazi üniversitesi Yayın No: 98, Ankara.

Alper, K., Çapacıoğlu, T. (2016). Bankacılık Sektöründe Likitide Pozisyonu ve Mevduat Faizleri ile İlişkisi, T.C. Merkez Bankası Ekonomi Notları, Sayı (2016-31).

Arslan, İ., (2007). Basel Kriterleri ve Türk Bankacılık Sektörüne Etkileri, Selçuk Üniversitesi Sosyal Bilimler Dergisi, 50-66.

Ball, R. \& Shivakumar, L. (2006). The Role of Accruals in Asymmetrically Timely Gain and Loss Recognition. Journal of Accounting Research, 44. DOI:10.1111/j.1475-679X.2006.00198.x

Basu, S. (1997). The Conservatism Principle and the Asymmetric Timeliness of Earnings. Journal of Accounting and Economics 24, 3-37. DOI:10.1016/S0165-4101(97)00014-1

Beaver, W.H. \& Ryan, S.G. (2005). Conditional and Unconditional Conservatism: Consepts and Modeling. Review of Accounting Studies, 10. DOI:10.1007/s11142-005-1532-6

Cemalcılar, Ö. \& Önce, S. (1999). Muhasebenin Kuramsal Yapısı, Anadolu Üniversitesi Yayın No:1093.

Delikanlı, İU. (2011). Finansal Düzenlemelerin İlke Bazlı Ya Da Kural Bazlı Olmasının Finansal Raporların Denetim Sürecine Etkisi. Ankara Üniversitesi SBF Dergisi. 66 (2), 73-92. DOI:10.1501/SBFder_0000002204

Erdoğan, N. \& Çubukçu, S. (2010). Tutuculuğun Kurumsal Yönetim Anlayışı Üzerindeki Etkileri. Muhasebe ve Denetime Bakış, Ekim, 53-66.

Ertuğrul, A.N. (2014). Geleneksel Muhasebeden Uluslararası Finansal Raporlamaya Geçişte İhtiyatll1ık Kavramı. Niğde Üniversitesi İ.İ.B.F Dergisi, 7(1).

Finansal Raporlamaya İlişkin Kavramsal Çerçeve Versiyon 2011 ve 2018, www.kgk.gov.tr

Givoly, D. \& Hayn, C. (2000). The Changing Time-Series Properties of Earnings, Cash Flows and Accruals: Has Financial Reporting Become More Conservative?. Journal of Accounting E Economics, 29(3). DOI:10.1016/S0165-4101(00)00024-0

Gör, Y. \& Tekin, B. (2018). Muhafazakar Muhasebe Uygulamalarının Kurumsallaşmış Şirketlerdeki Etkisi Üzerine Bir Araştırma. İşletme Araştırmaları Dergisi, 10(2). DOI: 10.20491/isarder.2018.416

Guay, W., \& Verrecchia, R. E. (2007). Conservative disclosure. Working paper. University of Pennsylvania. Alıntılayan: Juan Manuel Garcı'a Lara \& Beatriz Garcı' a Osma \& Fernando P. (2011). Conditional Conservatism And Cost of Capital. Rev Account Study 16:247-271 DOI 10.1007/s11142-010-9133-4, 247. DOI 10.1007/s11142-010-9133-4, 247

Hazar, A., Babuşçu, Ş., \&Tekindal, M.A. (2018). Bankacılık Sektöründe Sermaye Yeterliliği Rasyosunu Belirleyen Risklerin Analizi. UIIIID-ILEAS (20). DOI: 10.18092/ulikidince.261784 
Huang, W.(2018). Does Bank Competiton Affect Accounting Conservatism, Master Thesis., Arizona State University, ABD, 1-58. DOI:10.2139/ssrn.3439016

Kalaycı, Ş. (2005). SPSS Uygulamalı Çok Değgişkenli İstatistik Teknikleri, Asil Yayınları, Ankara.

Karabınar, S. (2005). Muhasebe İklimi, Seçkin Kitabevi, Ankara.

Kaytmaz Balsarı, Ç. \& Dalkılıç, F. (2007). Kural-Bazlı ve İlke-Bazlı Finansal Raporlama Standartlarının Karşılaştırılması. Muhasebe ve Denetime Bakış, Mayıs, 105-117.

Kiseleva, M. (2017). Relationship Between Accounting Conservatism and Liquidity Levels: Evidence From The Russian Sector. Master Thesis. St. Petersburg Üniveristesi.

Liu, C., Marchewka, J.T. , Lu, J. \& Yu, C.S. (2005). Beyond Concern: A Privacy-Trustbehavioral İntention Model of Electronic Commerce. Information\&Management, 42. DOI:10.1016/j.im.2004.01.003

Ruch, G.W. \& Taylor, G. (2015). Accounting Conservatism: A Review of The Literature. Journal of Accounting Literature , 34 , 17-38. DOI: 10.1016/j.acclit.2015.02.001

Sevilengül, O. (2016). Genel Muhasebe, Gazi Kitabevi, Ankara.

TMS 8, Muhasebe Politikaları, Muhasebe Tahminlerinde Değişiklikler ve Hatalar Standardı, www.kgk.gov.tr

Yıldırım, O. (2015). Türk Bankacılık Sisteminde Basel Kriterleri. Finans Politik E Ekonomik Yorumlar, 52 (609), 9-21.

Zaky, A. H.\& Soliman, M. (2017). The Impact of Announcement of Basel III on the Bnaking System Performance: An Empirical Research on Egyptian Banking Sector, The Business and Management Review, 9 (2), 165-174.

Zang, J. (2008). The Contracting Benefits of Accounting Conservatism to Lenders and Borrowers. Journal of Accounting and Economics, 45(1). DOI: 10.1016/j.jacceco.2007.06.002

Zeghal, D. \& Lahmar, Z. (2016). The Impact of IFRS Adoption on Accounting Conservatism in the European Union. International Journal of Accounting and Financial Reporting, 6(1) ISSN 2162-3082 2016, 127-160. DOI: 10.5296/ijafr.v6i1.9581

Zeytinoğlu, E. \& Polat, Z.G. (2018). Muhasebede İhtiyatlılı̆̆1 Etkileyen Faktörler: Borsa İstanbul Örneği. Journal Of Social and Humanities Sciences Research, 5(20). DOI:10.26450/jshsr.413

http://www.tmsf.gov.tr (Erişim Tarihi: 18.03.2020). 